\title{
Bacteroides faecis sp. nov., isolated from human faeces
}

\author{
Min-Soo Kim, ${ }^{1,2}$ Seong Woon Roh ${ }^{1,2}$ and Jin-Woo Bae ${ }^{1,2}$ \\ ${ }^{1}$ Department of Life and Nanopharmaceutical Sciences and Department of Biology, \\ Kyung Hee University, Seoul 130-701, Republic of Korea \\ ${ }^{2}$ University of Science \& Technology, Biological Resources Center, KRIBB, Daejeon 305-806, \\ Republic of Korea
}

Correspondence

Jin-Woo Bae

baejw@khu.ac.kr
Two anaerobic, Gram-negative, non-motile and non-spore-forming bacterial strains, designated MAJ27 $7^{\top}$ and MAJ26, were isolated from human faeces. Both isolates grew optimally at $37{ }^{\circ} \mathrm{C}$, were oxidase- and catalase-negative, were sensitive to bile and produced acid from fermentation of several substrates, including glucose. A study based on 16S rRNA gene sequences showed that both isolates were closely related to type strains of species of the genus Bacteroides. Comparisons of the isolates with Bacteroides thetaiotaomicron VPI $5482^{\top}$ and Bacteroides finegoldii JCM $13345^{\top}$ showed high levels of $16 \mathrm{~S}$ rRNA gene sequence similarity (98.6-98.7 and 96.9-97.0\%, respectively), but low levels of DNA-DNA relatedness ( $\leqslant 22 \%)$. The DNA G+C content $(42.7 \pm 1 \mathrm{~mol} \%)$ and the major fatty acid (anteiso- $\mathrm{C}_{15: 0}, 39.3-42.5 \%$ ) supported the assignment of the isolates to the genus Bacteroides. Based on phenotypic, chemotaxonomic, genotypic and phylogenetic studies, we propose that strains MAJ27 $7^{\top}$ and MAJ26 be classified as representing a novel species, Bacteroides faecis sp. nov. The type strain is MAJ2 $27^{\top}\left(=\mathrm{KCTC}^{\circ}\right.$ $\left.5823^{\top}=J C M 16478^{\top}\right)$.
Since the completion of the Human Genome Project, the contribution of symbiotic human gastrointestinal tract microbiota to normal physiology and predisposition to disease has been the focus of many studies (Turnbaugh et al., 2007). The phylum Bacteroidetes constitutes the dominant gastrointestinal microbiota, followed by the phylum Firmicutes (Eckburg et al., 2005; Gill et al., 2006; Palmer et al., 2007; Wang et al., 2005). Recently, it was reported that changes in the relative abundance of these phyla are associated with obesity (Turnbaugh et al., 2006). The phylum Bacteroidetes is composed of five major subgroups that constitute the Cytophaga-Flavobacter-Bacteroides (CFB) group and includes the genus Bacteroides (Gherna \& Woese, 1992). The phylum Bacteroidetes seems to account for about $23 \%$ of human intestinal microbiota (Eckburg et al., 2005; Frank et al., 2007; Hattori \& Taylor, 2009; Ley et al., 2005) and the genus Bacteroides seems to account for up to $20 \%$ (Matsuki et al., 2004; Rigottier-Gois et al., 2003).

Bacteria belonging to the genus Bacteroides are Gramnegative, non-spore-forming, non-motile, anaerobic rods

Abbreviation: CFB, Cytophaga-Flavobacter-Bacteroides.

The GenBank/EMBL/DDBJ accession numbers for the 16S rRNA gene sequences of strains MAJ27 ${ }^{\top}$ and MAJ26 are GQ496624 and GQ496623, respectively.

The biochemical characteristics and fatty acid compositions of strains MAJ27 ${ }^{\top}$ and MAJ26 and their closest phylogenetic neighbours are available with the online version of this paper. and are generally isolated from the gastrointestinal tract environment (Smith et al., 2006). Some species of the genus Bacteroides, including Bacteroides thetaiotaomicron, are known to be decomposers in the colon by fermenting carbohydrates and catabolizing polysaccharides (hemicellulose and xylan) (Falony et al., 2009; Flint, 2006; Salyers, 1995; Van der Meulen et al., 2006). Novel strains of members of the genus Bacteroides from human faeces and intestinal organs have been identified using cultureindependent techniques based on 16S rRNA gene sequence analysis (Dore et al., 1998; Eckburg et al., 2005; Gill et al., 2006; Hayashi et al., 2003; Li et al., 2009; Palmer et al., 2007) and several novel species have recently been identified and characterized (Bakir et al., 2006a, b, c; Chassard et al., 2008; Hayashi et al., 2007; Kitahara et al., 2005; Robert et al., 2007; Song et al., 2004).

In this study, two strains, designated MAJ $27^{\mathrm{T}}$ and MAJ26, were isolated from faeces of a healthy 26 -year-old male during a Korean study on the diversity of cultivable intestinal microbiota. The strains were isolated on supplemented brain heart diffusion medium (BHIS) containing $50 \mathrm{mg}$ kanamycin $\mathrm{l}^{-1}$ (Sigma) after 2 days at $37{ }^{\circ} \mathrm{C}$ in an anaerobic chamber (Bactron II; Shel Lab) containing $\mathrm{N}_{2} / \mathrm{H}_{2} / \mathrm{CO}_{2}(90: 5: 5)$ (Bacic \& Smith, 2008; Hecht, 2006; Smith et al., 2006). The isolates were subcultured on Eggerth-Gagnon (EG) medium supplemented with $5 \%$ horse blood under anaerobic conditions 
and stored as a suspension in $10 \%$ skimmed milk (BBL) with $10 \%$ glycerol at $-80{ }^{\circ} \mathrm{C}$. Reference strains $B$. thetaiotaomicron VPI $5482^{\mathrm{T}}$ and Bacteroides finegoldii $199^{\mathrm{T}}$ were obtained from DSMZ and KCTC, respectively, and maintained under the same conditions.

For phenotypic, chemotaxonomic and phylogenetic characterization, strains were cultivated on EG medium at $37^{\circ} \mathrm{C}$ and $\mathrm{pH}$ 7.6-7.8 for 2 or 3 days, unless otherwise stated. Growth of the isolates at 12, 15, 25, 30, 37, 43 and $47^{\circ} \mathrm{C}$ and under aerobic conditions was observed on PYG medium (DSMZ 104). To determine bile resistance, the isolates were cultivated on PYG medium supplemented with $0.1-0.4 \%(w / v)$ bile salts (Sigma). Gram staining was performed with a Gram staining kit (bioMérieux). Spore staining was determined with malachite green dye. Cell morphology and Gram and spore staining were observed using phase-contrast microscopy (Eclipse 50i; Nikon). Catalase and oxidase activities were investigated with $3 \%(\mathrm{v} / \mathrm{v})$ hydrogen peroxide solution and $1 \%(\mathrm{w} / \mathrm{v}) p-$ tetramethyl phenylenediamine solution (bioMérieux), respectively. The motility of the isolates was determined by stabbing the centre of a column of PYG medium containing $0.4 \%$ agar. Other phenotypic characteristics were determined using API 20A and Rapid ID 32A (bioMérieux), according to the manufacturer's instructions (Bakir et al., 2006a). The results of the biochemical analyses are given in Table 1, Supplementary Table S1 (available in IJSEM Online) and the species description.

Fatty acids of the isolates and B. thetaiotaomicron VPI $5482^{\mathrm{T}}$ were obtained from cells by saponification, methylation and extraction according to the Sherlock Microbial Identification System (MIDI, 1999). Fatty acid compositions were determined using GC (Hewlett Packard 6890) and analysed using Microbial Identification software (Sasser,
1990). The predominant fatty acids of strains MAJ27 ${ }^{\mathrm{T}}$ and MAJ26 were similar to those of B. thetaiotaomicron VPI $5482^{\mathrm{T}}$ (see Supplementary Table S2 in IJSEM Online). Strains MAJ27 ${ }^{\mathrm{T}}$ and MAJ26 contained anteiso- $\mathrm{C}_{15: 0}(42.5$ and $39.3 \%$, respectively) and iso- $\mathrm{C}_{17: 0} 3-\mathrm{OH}$ (14.8 and $14.2 \%$, respectively). Within the CFB group, large amounts of branched fatty acids are found (Brondz et al., 1991; Paster et al., 1994) and branched 15-carbon non-hydroxy and 17carbon 3-hydroxy acids are the predominant fatty acids for the genus Bacteroides (Mayberry et al., 1982).

For 16S rRNA gene sequence analysis, the genes of the isolates were amplified by colony PCR using four bacteriaspecific primers $(8 \mathrm{~F}, 968 \mathrm{~F}, 518 \mathrm{R}$ and 1492R; Baker et al., 2003). The PCR products were purified using a QIAquick PCR Purification kit (Qiagen) and sequenced using a BigDye Terminator Cycle Sequencing Ready Reaction kit (Applied Biosystems), according to the manufacturers' instructions. The reaction mixtures were analysed using an automated system (PRISM 3730XL DNA Analyzer; Applied Biosystems). The partial 16S rRNA gene sequences were assembled using DNASTAR in the SeqMan software package and compared with other sequences in the GenBank database. The isolates were found to be closely related to strains of species belonging to the genus Bacteroides. The $16 \mathrm{~S}$ rRNA gene sequence similarity between strain MAJ $27^{\mathrm{T}}$ and strain MAJ26 was $99.9 \%$. The $16 \mathrm{~S}$ rRNA gene sequence similarities between strains MAJ2 $7^{\mathrm{T}}$ and MAJ26 with B. thetaiotaomicron VPI $5482^{\mathrm{T}}$ were 98.8 and $98.7 \%$, respectively, and with $B$. finegoldii JCM $13345^{\mathrm{T}}$ were 97.0 and $96.9 \%$, respectively. The sequences from the isolates were aligned with 16S rRNA gene sequences of the genus Bacteroides from GenBank using the multiple sequence alignment program CLUSTAL_X (1.83) (Thompson et al., 1997). The trimmed alignment was converted to MEGA

Table 1. Comparative characteristics of Bacteroides faecis sp. nov. with closely related type strains of species of the genus Bacteroides

Taxa: 1, Bacteroides faecis sp. nov. ( $n=3)$; 2, B. thetaiotaomicron VPI $5482^{\mathrm{T}} ; 3$, B. finegoldii $199^{\mathrm{T}} ; 4$, B. ovatus ATCC $8483^{\mathrm{T}} ; 5$, B. xylanisolvens XB1A ${ }^{\mathrm{T}}$; 6, B. caccae ATCC $43185^{\mathrm{T}}$; 7, B. nordii WAL $11050^{\mathrm{T}} ; 8$, B. salyersiae WAL $10018^{\mathrm{T}}$. Data were taken from this study, Bakir et al. (2006a), Chassard et al. (2008), Johnson et al. (1986) and Song et al. (2004). All strains were positive for acid production from D-xylose, cellobiose and L-rhamnose and hydrolysis of aesculin. + , Positive; $\mathrm{w}$, weakly positive; $-^{+}$, most strains negative; - , negative.

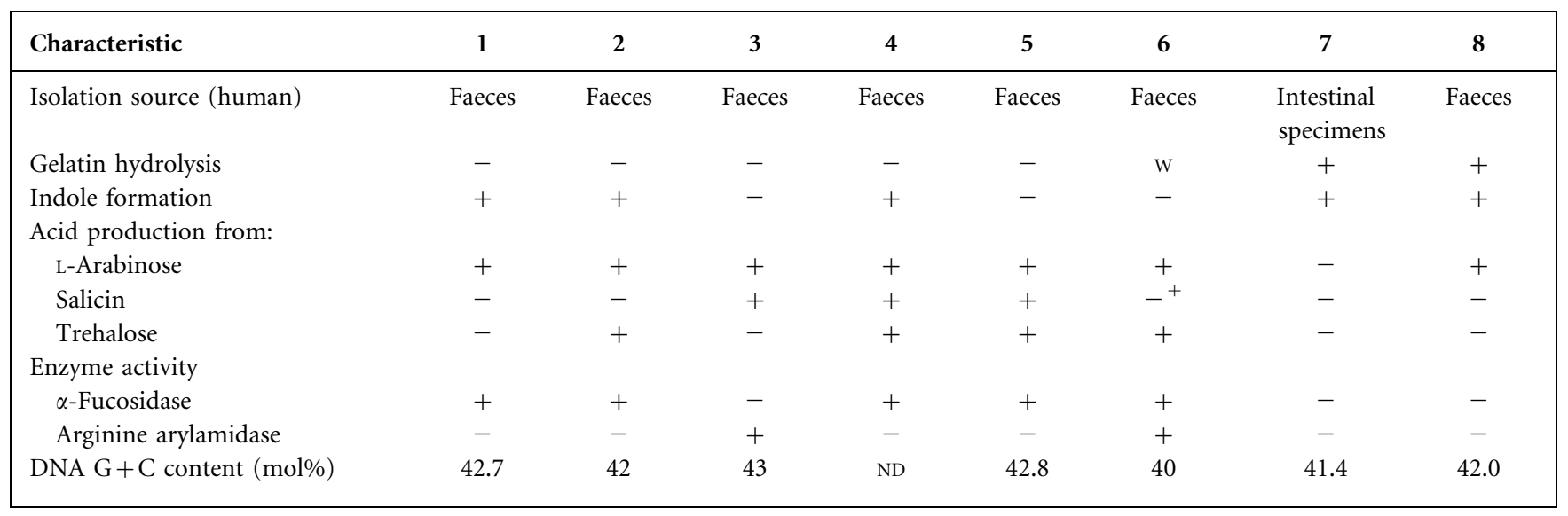


format for phylogenetic analyses. Phylogenetic consensus trees were constructed using the neighbour-joining and maximum-parsimony methods with MEGA4 (Tamura et al., 2007) and evaluated using 1000 bootstrap replicates (Kluge \& Farris, 1969; Saitou \& Nei, 1987). The phylogenetic analysis positioned the isolates within the Bacteroides group and also demonstrated that the isolates were closely related to $B$. thetaiotaomicron VPI $5482^{\mathrm{T}}$ and $B$. finegoldii JCM $13345^{\mathrm{T}}$ (Fig. 1).
Genomic DNA of the isolates and the reference strains was extracted using a G-spin Genomic DNA Extraction kit (Intron Biotechnology). DNA-DNA hybridization was performed using the fluorometric method described by Ezaki et al. (1989) with modifications (Hirayama et al., 1996). As reported by Wayne et al. (1987), strains with DNA-DNA relatedness $>70 \%$ are generally considered as belonging to the same species. DNA-DNA relatedness between strain $\mathrm{MAJ} 27^{\mathrm{T}}$ and strain MAJ26 was $97 \%$,

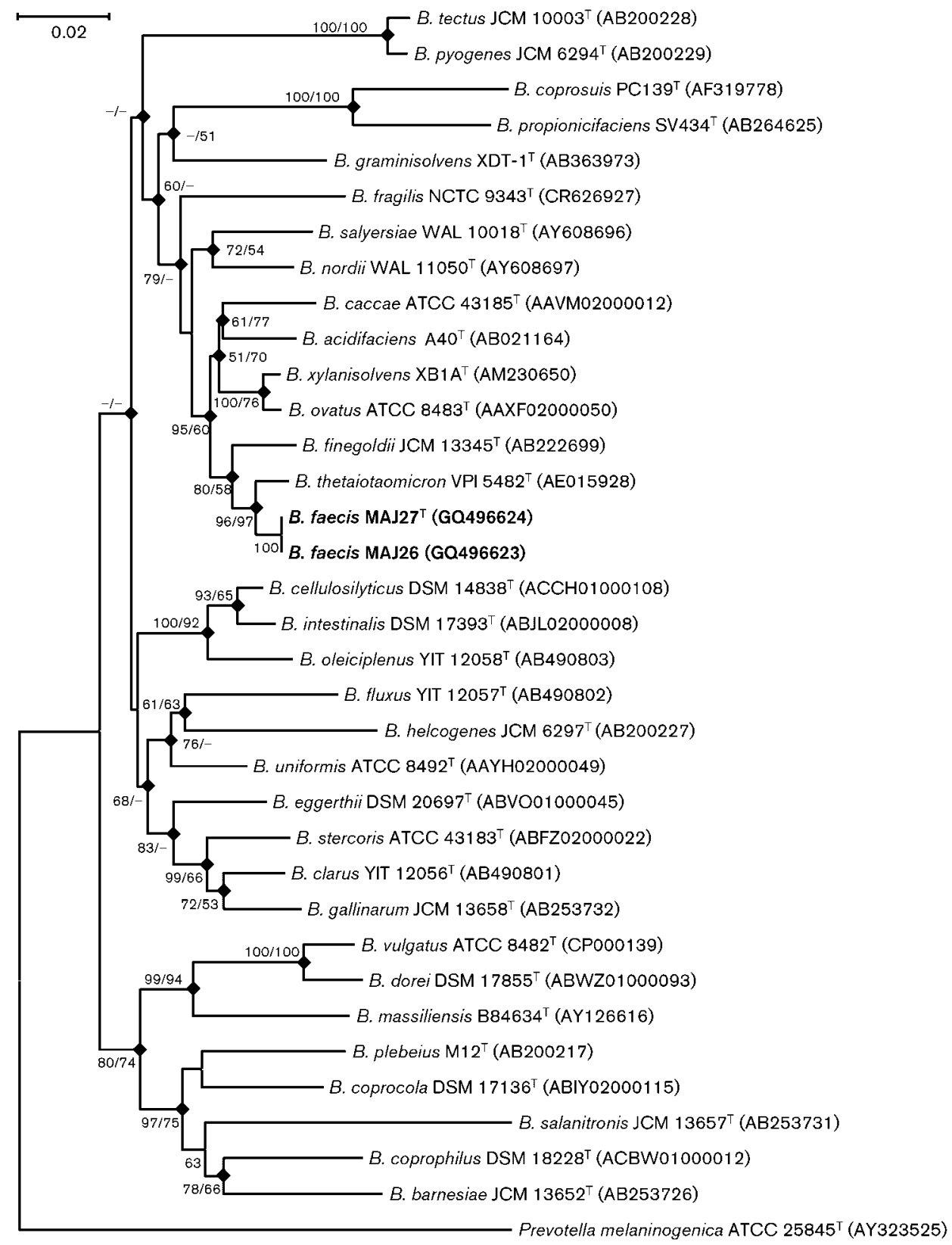

Fig. 1. Neighbour-joining phylogenetic tree based on 16S rRNA gene sequences showing the phylogenetic position of strains MAJ $27^{\top}$ and MAJ26. Filled diamonds indicate that the corresponding nodes were also recovered in trees generated with the maximum-parsimony method. Bootstrap values (>50\%) based on 1000 replicates for the neighbour-joining and maximumparsimony methods, respectively, are shown at branch nodes. Bar, 0.02 substitutions per site. 
between strain MAJ $27^{\mathrm{T}}$ and B. thetaiotaomicron VPI $5482^{\mathrm{T}}$ was $22 \%$ and between strain MAJ27 $7^{\mathrm{T}}$ and B. finegoldii $199^{\mathrm{T}}$ was $21 \%$. This indicated that the isolates belonged to a single novel species of the genus Bacteroides. The DNA $\mathrm{G}+\mathrm{C}$ content of the isolates was determined using a fluorometric method with SYBR Green I and real-time PCR (Gonzalez \& Saiz-Jimenez, 2002). The genomic DNA of Escherichia coli K-12 was used as the calibration reference (Gonzalez \& Saiz-Jimenez, 2002). The DNA $\mathrm{G}+\mathrm{C}$ content of the isolates was $42.7 \pm 1 \mathrm{~mol} \%$, which fell within the limits of the range reported for the genus Bacteroides (40-48 mol\%; Shah, 1992).

On the basis of phenotypic, chemotaxonomic, genotypic and phylogenetic studies, we propose that strain MAJ $27^{\mathrm{T}}$ and strain MAJ26 be classified as representing a novel species of the genus Bacteroides, for which the name Bacteroides faecis sp. nov. is proposed.

\section{Description of Bacteroides faecis sp. nov.}

Bacteroides faecis (fa.e'cis. L. gen. n. faecis of dregs, of faeces, referring to faecal origin).

Anaerobic, Gram-negative, non-motile and non-sporeforming rods, $1.5-2.0 \mu \mathrm{m}$ in length and $1.0 \mu \mathrm{m}$ in width, generally observed singly. After cultivation on PYG medium at $37{ }^{\circ} \mathrm{C}$ for 4 days, colonies are pale yellow, circular, glistening and convex with a buttery texture and $1.0-1.5 \mathrm{~mm}$ in diameter. Grows at $25-43{ }^{\circ} \mathrm{C}$ (optimum $37{ }^{\circ} \mathrm{C}$ ). Oxidase-, catalase- and urease-negative and indolepositive. Sensitive to bile. Hydrolyses aesculin, but not gelatin. With API 20A, produces acid from L-arabinose, cellobiose, D-glucose, lactose, maltose, D-mannose, raffinose, L-rhamnose, sucrose and D-xylose, but not from glycerol, D-mannitol, melezitose, salicin, D-sorbitol or trehalose. With API Rapid ID 32A, positive for $\alpha$ fucosidase, $\alpha$ - and $\beta$-galactosidases, $\alpha$ - and $\beta$-glucosidases, $N$-acetyl- $\beta$-glucosaminidase, glutamic acid decarboxylase, alkaline phosphatase, leucyl glycine arylamidase, alanine arylamidase, glutamyl glutamic acid arylamidase, production of indole and fermentation of D-mannose and raffinose, but negative for $\beta$-galactosidase 6-phosphate, $\alpha$ arabinosidase, $\beta$-glucuronidase, urease, arginine dihydrolase, arginine arylamidase, proline arylamidase, phenylalanine arylamidase, leucine arylamidase, pyroglutamic acid arylamidase, tyrosine arylamidase, glycine arylamidase, histidine arylamidase, serine arylamidase and reduction of nitrate. The major fatty acids are anteiso- $C_{15: 0}$, iso- $C_{17: 0}$ 3-OH and $\mathrm{C}_{16: 0} 3-\mathrm{OH}$. The DNA G $+\mathrm{C}$ content of the type strain is $42.7 \pm 1 \mathrm{~mol} \%$.

The type strain, MAJ $27^{\mathrm{T}}\left(=\right.$ KCTC $\left.5823^{\mathrm{T}}=\mathrm{JCM} 16478^{\mathrm{T}}\right)$, was isolated from human faeces. Strain MAJ26 $(=$ KCTC $5822=J C M \quad 16477)$ is a reference strain.

\section{Acknowledgements}

This research was supported by Korea Food \& Drug Administration (grant no. 09172KFDA996).

\section{References}

Bacic, M. K. \& Smith, C. J. (2008). Laboratory maintenance and cultivation of bacteroides species. Curr Protoc Microbiol 13, Unit 13C.1.

Baker, G. C., Smith, J. J. \& Cowan, D. A. (2003). Review and reanalysis of domain-specific $16 \mathrm{~S}$ primers. J Microbiol Methods 55, 541555.

Bakir, M. A., Kitahara, M., Sakamoto, M., Matsumoto, M. \& Benno, Y. (2006a). Bacteroides finegoldii sp. nov., isolated from human faeces. Int J Syst Evol Microbiol 56, 931-935.

Bakir, M. A., Kitahara, M., Sakamoto, M., Matsumoto, M. \& Benno, Y. (2006b). Bacteroides intestinalis sp. nov., isolated from human faeces. Int J Syst Evol Microbiol 56, 151-154.

Bakir, M. A., Sakamoto, M., Kitahara, M., Matsumoto, M. \& Benno, Y. (2006c). Bacteroides dorei sp. nov., isolated from human faeces. Int $J$ Syst Evol Microbiol 56, 1639-1643.

Brondz, I., Olsen, I., Haapasalo, M. \& Van Winkelhoff, A. J. (1991). Multivariate analyses of fatty acid data from whole-cell methanolysates of Prevotella, Bacteroides and Porphyromonas spp. J Gen Microbiol 137, 1445-1452.

Chassard, C., Delmas, E., Lawson, P. A. \& Bernalier-Donadille, A. (2008). Bacteroides xylanisolvens sp. nov., a xylan-degrading bacterium isolated from human faeces. Int J Syst Evol Microbiol 58, 10081013.

Dore, J., Sghir, A., Hannequart-Gramet, G., Corthier, G. \& Pochart, P. (1998). Design and evaluation of a $16 \mathrm{~S}$ rRNA-targeted oligonucleotide probe for specific detection and quantitation of human faecal Bacteroides populations. Syst Appl Microbiol 21, 65-71.

Eckburg, P. B., Bik, E. M., Bernstein, C. N., Purdom, E., Dethlefsen, L., Sargent, M., Gill, S. R., Nelson, K. E. \& Relman, D. A. (2005). Diversity of the human intestinal microbial flora. Science 308, 1635-1638.

Ezaki, T., Hashimoto, Y. \& Yabuuchi, E. (1989). Fluorometric deoxyribonucleic acid-deoxyribonucleic acid hybridization in microdilution wells as an alternative to membrane filter hybridization in which radioisotopes are used to determine genetic relatedness among bacterial strains. Int J Syst Bacteriol 39, 224-229.

Falony, G., Calmeyn, T., Leroy, F. \& De Vuyst, L. (2009). Coculture fermentations of Bifidobacterium species and Bacteroides thetaiotaomicron reveal a mechanistic insight into the prebiotic effect of inulintype fructans. Appl Environ Microbiol 75, 2312-2319.

Flint, H. J. (2006). The significance of prokaryote diversity in the human gastrointestinal tract. In Prokaryotic Diversity: Mechanisms and Significance (Society for General Microbiology Symposium no. 66), pp. 65-90. Edited by N. A. Logan. H. M. Lappin-Scott \& P. C. F. Oyston. Cambridge: Cambridge University Press.

Frank, D. N., St Amand, A. L., Feldman, R. A., Boedeker, E. C., Harpaz, N. \& Pace, N. R. (2007). Molecular-phylogenetic characterization of microbial community imbalances in human inflammatory bowel diseases. Proc Natl Acad Sci U S A 104, 13780-13785.

Gherna, R. \& Woese, C. R. (1992). A partial phylogenetic analysis of the 'flavobacter-bacteroides' phylum: basis for taxonomic restructuring. Syst Appl Microbiol 15, 513-521.

Gill, S. R., Pop, M., Deboy, R. T., Eckburg, P. B., Turnbaugh, P. J., Samuel, B. S., Gordon, J. I., Relman, D. A., Fraser-Liggett, C. M. \& Nelson, K. E. (2006). Metagenomic analysis of the human distal gut microbiome. Science 312, 1355-1359.

Gonzalez, J. M. \& Saiz-Jimenez, C. (2002). A fluorometric method for the estimation of $\mathrm{G}+\mathrm{C}$ mol\% content in microorganisms by thermal denaturation temperature. Environ Microbiol 4, 770-773.

Hattori, M. \& Taylor, T. D. (2009). The human intestinal microbiome: a new frontier of human biology. DNA Res 16, 1-12. 
Hayashi, H., Sakamoto, M., Kitahara, M. \& Benno, Y. (2003). Molecular analysis of fecal microbiota in elderly individuals using $16 \mathrm{~S}$ rDNA library and T-RFLP. Microbiol Immunol 47, 557-570.

Hayashi, H., Shibata, K., Bakir, M. A., Sakamoto, M., Tomita, S. \& Benno, Y. (2007). Bacteroides coprophilus sp. nov., isolated from human faeces. Int J Syst Evol Microbiol 57, 1323-1326.

Hecht, D. W. (2006). Anaerobes: Antibiotic resistance, clinical significance, and the role of susceptibility testing. Anaerobe 12, 115121.

Hirayama, H., Tamaoka, J. \& Horikoshi, K. (1996). Improved immobilization of DNA to microwell plates for DNA-DNA hybridization. Nucleic Acids Res 24, 4098-4099.

Johnson, J. L., Moore, W. E. C. \& Moore, L. V. H. (1986). Bacteroides caccae sp. nov., Bacteroides merdae sp. nov., and Bacteroides stercoris sp. nov. isolated from human feces. Int J Syst Bacteriol 36, 499-501.

Kitahara, M., Sakamoto, M., Ike, M., Sakata, S. \& Benno, Y. (2005). Bacteroides plebeius sp. nov. and Bacteroides coprocola sp. nov., isolated from human faeces. Int J Syst Evol Microbiol 55, 2143-2147.

Kluge, A. G. \& Farris, J. S. (1969). Quantitative phyletics and the evolution of anurans. Syst Zool 18, 1-32.

Ley, R. E., Bäckhed, F., Turnbaugh, P., Lozupone, C. A., Knight, R. D. \& Gordon, J. I. (2005). Obesity alters gut microbial ecology. Proc Natl Acad Sci U S A 102, 11070-11075.

Li, M., Zhou, H., Hua, W., Wang, B., Wang, S., Zhao, G., Li, L., Zhao, L. \& Pang, X. (2009). Molecular diversity of Bacteroides spp. in human fecal microbiota as determined by group-specific 16S rRNA gene clone library analysis. Syst Appl Microbiol 32, 193-200.

Matsuki, T., Watanabe, K., Fujimoto, J., Kado, Y., Takada, T., Matsumoto, K. \& Tanaka, R. (2004). Quantitative PCR with $16 \mathrm{~S}$ rRNA-gene-targeted species-specific primers for analysis of human intestinal bifidobacteria. Appl Environ Microbiol 70, 167-173.

Mayberry, W. R., Lambe, D. W., Jr \& Ferguson, K. P. (1982). Identification of Bacteroides species by cellular fatty acid profiles. Int $J$ Syst Bacteriol 32, 21-27.

MIDI (1999). Sherlock Microbial Identification System Operating Manual, version 3.0. Newark, DE: MIDI, Inc.

Palmer, C., Bik, E. M., DiGiulio, D. B., Relman, D. A. \& Brown, P. O. (2007). Development of the human infant intestinal microbiota. PLoS Biol 5, e177.

Paster, B. J., Dewhirst, F. E., Olsen, I. \& Fraser, G. J. (1994). Phylogeny of Bacteroides, Prevotella, and Porphyromonas spp. and related bacteria. J Bacteriol 176, 725-732.

Rigottier-Gois, L., Rochet, V., Garrec, N., Suau, A. \& Dore, J. (2003). Enumeration of Bacteroides species in human faeces by fluorescent in situ hybridisation combined with flow cytometry using 16S rRNA probes. Syst Appl Microbiol 26, 110-118.

Robert, C., Chassard, C., Lawson, P. A. \& Bernalier-Donadille, A. (2007). Bacteroides cellulosilyticus sp. nov., a cellulolytic bacterium from the human gut microbial community. Int J Syst Evol Microbiol 57, 1516-1520.

Saitou, N. \& Nei, M. (1987). The neighbor-joining method: a new method for reconstructing phylogenetic trees. Mol Biol Evol 4, 406425.

Salyers, A. A. (1995). Fermentation of polysaccharides by human colonic anaerobes. In Dietary Fibre: Mechanisms of Action in Human Physiology and Metabolism, pp. 29-35. Edited by C. Cherbut, J. L. Barry, D. Lairon \& M. Durand. Paris, John Libbey Eurotext.

Sasser, M. (1990). Identification of bacteria by gas chromatography of cellular fatty acids. USFCC Newsl 20, 16.

Shah, H. N. (1992). The genus Bacteroides and related taxa. In The Prokaryotes, 2nd edn, pp. 3593-3607. Edited by A. Balows, H. G. Trüper, M. Dworkin, W. Harder \& K. H. Schleifer. New York: Springer.

Smith, C. J., Rocha, E. R. \& Paster, B. J. (2006). The medically important Bacteroides spp. in health and disease. In The Prokaryotes: $a$ Handbook on the Biology of Bacteria, 3rd edn, vol. 7, pp. 381-427. Edited by M. Dworkin, S. Falkow, E. Rosenberg, K. H. Schleifer \& E. Stackebrandt. New York: Springer.

Song, Y. L., Liu, C. X., McTeague, M. \& Finegold, S. M. (2004). 'Bacteroides nordii' sp. nov. and 'Bacteroides salyersae' sp. nov. isolated from clinical specimens of human intestinal origin. J Clin Microbiol 42, 5565-5570.

Tamura, K., Dudley, J., Nei, M. \& Kumar, S. (2007). MEGA4: Molecular evolutionary genetics analysis (MEGA) software version 4.0. Mol Biol Evol 24, 1596-1599.

Thompson, J. D., Gibson, T. J., Plewniak, F., Jeanmougin, F. \& Higgins, D. G. (1997). The CLUSTAL_X windows interface: flexible strategies for multiple sequence alignment aided by quality analysis tools. Nucleic Acids Res 25, 4876-4882.

Turnbaugh, P. J., Ley, R. E., Hamady, M., Fraser-Liggett, C. M., Knight, R. \& Gordon, J. I. (2007). The human microbiome project. Nature 449, 804-810.

Turnbaugh, P. J., Ley, R. E., Mahowald, M. A., Magrini, V., Mardis, E. R. \& Gordon, J. I. (2006). An obesity-associated gut microbiome with increased capacity for energy harvest. Nature 444, 1027-1031.

Van der Meulen, R. D., Makras, L., Verbrugghe, K., Adriany, T. \& De Vuyst, L. (2006). In vitro kinetic analysis of oligofructose consumption by Bacteroides and Bifidobacterium spp. indicates different degradation mechanisms. Appl Environ Microbiol 72, 1006-1012.

Wang, M., Ahrne, S., Jeppsson, B. \& Molin, G. (2005). Comparison of bacterial diversity along the human intestinal tract by direct cloning and sequencing of 16S rRNA genes. FEMS Microbiol Ecol 54, 219-231.

Wayne, L. G., Brenner, D. J., Colwell, R. R., Grimont, P. A. D., Kandler, O., Krichevsky, M. I., Moore, L. H., Moore, W. E. C., Murray, R. G. E. \& other authors (1987). International Committee on Systematic Bacteriology. Report of the ad hoc committee on reconciliation of approaches to bacterial systematics. Int J Syst Bacteriol 37, 463-464. 